\title{
Variation in Aromatase Activity in the Medial Preoptic Area and Plasma Progesterone Is Associated with the Onset of Paternal Behavior
}

\author{
Brian C. Trainor $^{a}$ Ian M. Bird ${ }^{b}$ Noel A. Aldayc Barney A. Schlinger ${ }^{c}$ \\ Catherine A. Marlera \\ ${ }^{a}$ Department of Psychology, University of Wisconsin at Madison, Madison, Wisc.; b Department of \\ Obstetrics and Gynecology, University of Wisconsin Medical School, 7E Meriter Hospital, Madison, Wisc., and \\ 'Department of Physiological Science, University of California Los Angeles, Los Angeles, Calif., USA
}

\author{
Key Words \\ Aromatase $\cdot$ Preoptic area $\cdot$ Paternal behavior $\cdot$ Gonadal \\ steroids · Mice
}

\begin{abstract}
The effects of aromatase within the brain on sexual behavior have been studied in a wide variety of species. Relatively few non-mating behaviors have been considered, despite evidence that estrogen affects many social behaviors. Testosterone promotes paternal behavior in California mouse (Peromyscus californicus) fathers, acting primarily via aromatization to estradiol. Virgin male California mice rarely exhibit paternal behavior, so we investigated whether aromatase in the brain changed with the onset of paternal behavior in California mouse fathers. In the medial preoptic area (MPOA), a brain area known to regulate parental behavior in rodents, we found that fathers had significantly more aromatase activity than mated males without pups, suggesting that an increase in estrogen production in this brain area contributes to the onset of paternal behavior. We also found that progesterone $\left(P_{4}\right)$ levels were lower in fathers compared to sexually inexperienced males and that $\mathrm{P}_{4}$ was negatively correlated with aromatase activity in the MPOA. These $\mathrm{P}_{4}$ findings agree with a recent study that found an inhibitory effect of $\mathrm{P}_{4}$ on paternal behavior.
\end{abstract}

\section{KARGER}

Fax + 41613061234

E-Mail karger@karger.ch

www.karger.com
(C) 2003 S. Karger AG, Basel

Accessible online at: www. karger.com/nen
Overall, we found that aromatase activity and $\mathrm{P}_{4}$ levels change in association with an important life history transition, and may provide a mechanistic basis for plasticity in paternal behavior.

Copyright $\odot 2003$ S. Karger AG, Basel

\section{Introduction}

Aromatase located in the hypothalamus and limbic system regulates a variety of social behaviors including courtship [1], aggression [2, 3], and sexual behavior [4, 5]. Investigations of the function and regulation of neural aromatase in mammals have been conducted in a wide variety of species including marsupial [6], ovine [7], primate [8], and rodent [9, 10] model systems. The great majority of studies on the behavioral effects of aromatase have focused on mating behaviors in sexually inexperienced males. In both avian [11] and mammalian [12] species, testosterone promotes the expression of mating behavior via conversion to estradiol $\left(\mathrm{E}_{2}\right)$ by aromatase. The distribution of aromatase in the mammalian brain is limited primarily to hypothalamic and limbic brain areas $[8,10,13]$, including the medial preoptic area (MPOA), bed nucleus of the stria terminalis (BNST), ventromedial hypothalamus (VMH), and medial amygdala (MA). In particular, the MPOA is a critical site of aromatization for 
the expression of mating behaviors [11, 14]. Aromatase in other hypothalamic and limbic brain areas may also be important for mating, as a variety of studies indicate that estrogen may act at the BNST, MA, and VMH to mediate mating behaviors in rodents [for reviews see, 15, 16].

Recent correlational studies have revealed that variation in aromatase is associated with other types of social behavior. Neonatal house mice from a line selected for short attack latency in an aggression test had more aromatase enzyme activity within the amygdala than neonatal mice from a line selected for long attack latency [17]. Also, male rams that preferred to associate with other males had lower levels of aromatase activity in the MPOA compared to rams that preferred to associate with females [18]. These studies suggest that brain aromatase may have versatile functions outside of regulating sexual behavior. A hallmark of many neuroendocrine systems is that they are responsive to social stimuli $[19,20]$. However, descriptions of plasticity in neural aromatase have focused primarily on developmental changes in mammals [21] or seasonal changes in birds $[22,23]$. Recent evidence indicates that the conversion of testosterone to $\mathrm{E}_{2}$ by aromatase is an important neuroendocrine mechanism promoting paternal behavior in the monogamous California mouse, Peromyscus californicus [24]. Sexually inexperienced male California mice generally do not exhibit paternal behavior $[25,26]$. This suggests that changes in neural aromatase may be associated with the onset of paternal behavior in fathers.

Studies in several mammalian species suggest that testosterone is involved in the regulation of male parental behavior in mammals. In two paternal rodents, androgen levels are elevated before pups are born and drop after parturition $[27,28]$. A previous study found no significant differences in testosterone levels between fathers and nonfathers in California mice, although sample sizes may not have been large enough to detect significant differences [25]. Studies of paternal callitrichid monkeys found somewhat contrasting results. In the cotton-top tamarin ( $\mathrm{Sa}$ guinus oedipus) male urinary testosterone levels increase during a partner's pregnancy and remain elevated after parturition [29], while in the related black tuft-eared marmoset (Callithrix kuhlii), urinary testosterone levels were negatively correlated with paternal behavior [30]. Hormone manipulations in rodents have also indicated variation in testosterone function. Castrated Mongolian gerbils (Meriones unguiculatus) expressed higher rates of paternal behavior than intact males [31], while the effect of castration in adult male prairie voles (Microtus ochrogaster) has been inconsistent [32, 33]. However, sexually inexpe- rienced male prairie voles spontaneously show paternal behaviors [32], and a recent study showed that testosterone acts postnatally to facilitate paternal behavior in adult males [34]. In the California mouse ( $P$. californicus) males only exhibit paternal behavior consistently after the birth of their own pups $[25,26]$, and testosterone promotes paternal behavior in fathers $[35,36]$. This effect occurs primarily via aromatization as castrated males treated with testosterone or $E_{2}$ express higher levels of paternal behavior than those treated with dihydrotestosterone (DHT) or empty implants, and aromatase inhibition blocks the positive effect of testosterone on paternal behavior, but not that of $E_{2}$ [24]. $E_{2}$ levels in plasma are undetectable [24], suggesting that the brain is a primary site of aromatization.

The MPOA has been implicated as an important brain area that promotes both maternal [37] and paternal behavior [38, 39]. In contrast, the MA and VMH form a circuit that inhibits maternal behavior [40, 41]. We hypothesized that aromatase levels in some, or all, of these brain regions would change in association with the onset of paternal behavior in fathers. In particular, we expected that aromatase activity would increase in the MPOA, as $E_{2}$ has been found to act in this region to promote parental behaviors in male and female mammals. We also measured aromatase activity in the hippocampus (HPC) as a control because this region has not been implicated in the control of parental behaviors. Finally we examined plasma testosterone, DHT, and progesterone $\left(\mathrm{P}_{4}\right)$ levels to observe how these hormones changed with reproductive experiences, and to see if changes in these hormones could explain variation in aromatase activity.

\section{Methods}

\section{Subjects}

We used male California mice reared in a laboratory colony at the University of Wisconsin, Madison, Wisc., USA. Subjects were housed in standard cages and were fed Purina 5001 mouse chow and water ad libitum. Colony rooms were kept under a 14:10-hour light:dark cycle with lights on at $05.00 \mathrm{~h}$. Animals were maintained in accordance with the recommendations of the National Institutes of Health Guide for the Care and Use of Laboratory Animals. Agematched males with no prior sexual experience were randomly assigned to 1 of 3 experimental groups: sexually inexperienced; mated, or reproductively experienced (fathers). Mated males were paired with a female for 2 weeks before brains were collected. Fathers were paired to a female until 2-3 weeks after a litter was born. Males assigned to the inexperienced group were never individually housed and brains were collected at the same time as brains from males in the other experimental groups. We also compared $\mathrm{P}_{4}$ levels between 
castrated males with testosterone replacement implants $(1 \mathrm{~mm}$ testosterone, 0.04 in i.d., 0.085 in o.d.), singly housed males, and group housed males (equivalent to sexually inexperienced males used in aromatase activity experiment). Castrated males were singly housed and blood samples were collected 3 weeks after surgery.

\section{Tissue Collection}

All males were lightly anesthetized with isoflurane and decapitated between 08.30 and $10.00 \mathrm{~h}$. Brains were rapidly removed and dissected on ice using the Palkovitz punch technique. Selected brain areas were dissected with the use of a brain matrix to generate coronal slices [42]. The MPOA and BNST were collected from a slice starting at the optic chiasm and ending $2 \mathrm{~mm}$ anterior. The MA, $\mathrm{VMH}$, and HPC were collected from a slice starting at the optic chiasm and ending $2 \mathrm{~mm}$ posterior. Each slice was frozen at $-20^{\circ} \mathrm{C}$ on a freezing plate. Bilateral samples of the MPOA and BNST were collected with a $1,000-\mu \mathrm{m}$ punch and bilateral samples of the MA, $\mathrm{VMH}$, and HPC were collected with a 750- $\mu \mathrm{m}$ punch [13]. Brain samples were frozen on dry ice and stored at $-80^{\circ} \mathrm{C}$ for aromatase assays. Trunk blood was collected and centrifuged. Plasma was removed and stored at $-80^{\circ} \mathrm{C}$ for hormone assays. One blood sample from a sexually inexperienced male was lost during collection.

\section{Aromatase Activity Assays}

To measure aromatase activity we used a tritiated water assay that quantifies the production of estrogen by measuring the transfer of tritium at the $1 \beta$ position of $\left[1 \beta-{ }^{3} \mathrm{H}\right]$ androstenedione $(1 \beta-\mathrm{AE})$ to water, which is proportional to the amount of estrogen formed [43]. To confirm that this assay measured the production of estrogen by aromatase, we also used a product isolation assay that measured the conversion of $\left[1,2,6,7-{ }^{3} \mathrm{H}\right]$ androstenedione $\left({ }^{3} \mathrm{H}-\mathrm{AE}\right.$; NEN, specific activity $\left.10^{5} \mathrm{Ci} / \mathrm{mmol}\right)$ to $\left[{ }^{3} \mathrm{H}\right]$ estrone $\left(\mathrm{E}_{1}\right)$ [44]. We used both methods to conduct validation assays on homogenate pools made from California mouse brain tissue punches (MPOA, BNST, MA, and $\mathrm{VMH}$ ). Previous comparisons of the tritiated water assay and methods measuring estrogenic products have shown that these assays can produce comparable results [43].

Assay conditions were determined using the product isolation assay. Tissue punch samples from the MPOA, BNST, MA, and VMH were pooled and homogenized in ice-cold sucrose/phosphate buffer $\left(\mathrm{SPO}_{4}, 250 / 50 \mathrm{~m} M, \mathrm{pH} 7.15\right)$. For a time course, $270-\mu 1$ aliquots of tissue homogenate were incubated with $250 \mathrm{n} M{ }^{3} \mathrm{H}-\mathrm{AE}$ for 30,60 and $90 \mathrm{~min}$ at $37^{\circ} \mathrm{C}$. For an aromatase saturation analysis, $180-\mu 1$ aliquots of tissue homogenate were incubated with 50,100, 250 and $500 \mathrm{n} M^{3} \mathrm{H}-\mathrm{AE}$ for $60 \mathrm{~min}$ at $37^{\circ} \mathrm{C}$. Aliquots of homogenate were incubated with ${ }^{3} \mathrm{H}-\mathrm{AE}$ in the presence of a NADH-NADPH-generating system and incubated at $37^{\circ} \mathrm{C}$. Control tubes contained substrate and cofactors but no tissue. Recovery tubes were used to determine procedural loss by adding approximately $200,000 \mathrm{cpm}$ of ${ }^{3} \mathrm{H}-\mathrm{E}_{1}$ to a tube of $\mathrm{SPO}_{4}$ buffer without substrate. Incubations were halted by the snap-freezing method in a methanol/dry ice bath. Radioactive metabolites were extracted three times with $3 \mathrm{ml}$ of HPLC grade ethyl ether. The organic ether layer was removed, dried and reconstituted in $\mathrm{MeOH} /$ methylene chloride (1:1). Estrogenic products were separated from androgens through a phenolic partition using $\mathrm{CCl}_{4}$ and $0.1 N \mathrm{NaOH}(1: 1)$. Estrogens were then extracted from the $\mathrm{NaOH}$ three times with $2 \mathrm{ml}$ of ethyl acetate, evaporated in a water bath, and reconstituted in $\mathrm{MeOH} /$ methylene chloride. Radioactive substrates were chromatographed on TLC plates (Analtech, Inc., Newark, Dela., USA) twice in 3:1 ether/hexane. Silica gel corre- sponding to estrogen products was scraped and eluted in $\mathrm{MeOH} / \mathrm{H}_{2} \mathrm{O}$ (10:1). A 300- $\mu 1$ aliquot of each eluate was added to scintillation vials containing $5 \mathrm{ml}$ of Scintisafe 30\% (FisherScientific, Pittsburgh, Pa., USA) for quantification of radioactivity using a Beckman LS 9000 scintillation counter. Recovery of authentic ${ }^{3} \mathrm{H}-\mathrm{E}_{1}$ was calculated to be $20.3 \%$ and was used to correct for procedural losses. Results are expressed as femtomoles of product per milligram of protein with the criterion for detectable product formation being 2 times above background. The authenticity of the ${ }^{3} \mathrm{H}-\mathrm{E}_{1}$ formed in these reactions was confirmed by recrystallization of the product to constant specific activity producing a recovery of $89 \%$ with a minimal error of $4.7 \%$.

We replicated and extended the time-course study, and performed a dose-response experiment with aromatase antagonists using the water assay $[10,45]$. In all experiments conducted with this assay, each sample was homogenized in $150 \mu \mathrm{l}$ of $\mathrm{SPO}_{4}$ and was frozen at $-80^{\circ} \mathrm{C}$ overnight. A $10-\mu$ l aliquot of each homogenized tissue sample was assayed for protein content prior to each aromatase assay so that protein levels could be normalized. For the time-course and fadrozole dose-response experiments, we used 100- $\mu$ l aliquots of a homogenate pool comprised of tissue punch samples from the MPOA, BNST, MA, and VMH. For assays of experimental tissue, we used $80 \mu \mathrm{l}$ of homogenate for the MPOA, $80 \mu \mathrm{l}$ for the BNST, $100 \mu \mathrm{l}$ for the MA, $100 \mu \mathrm{l}$ for the $\mathrm{VMH}$, and $100 \mu \mathrm{l}$ for the HPC in aromatase assays. The incubation of homogenates was carried out as previously described except that $1 \beta-\mathrm{AE}$ was used as substrate $(200 \mathrm{n} M$, $1 \mu \mathrm{Ci} /$ tube), and the reaction was stopped using liquid nitrogen. After freezing, $0.3 \mathrm{ml}$ of ice-cold water was added to each sample. Radiolabeled steroids were removed by extraction with $1 \mathrm{ml}$ of chloroform. Phases were separated by brief centrifugation and an aliquot of the upper aqueous phase was recovered and mixed with $0.6 \mathrm{ml}$ of charcoal/dextran $(5 / 0.5 \% \mathrm{wt} / \mathrm{vol})$. After centrifugation to pellet the charcoal, $1 \mathrm{ml}$ of the aqueous phase was removed and radioactivity determined in a liquid scintillation counter. For the time course and dose-response studies, tissue punch samples were pooled together and homogenized in $\mathrm{SPO}_{4}$. In the time course study aliquots of homogenate pool were incubated for 30,60, 90, 120, and $240 \mathrm{~min}$. We also determined the effects of the competitive aromatase antagonist 4-OH-AE [46] at $10 \mu M$. Finally, we conducted a dose-response study using the aromatase antagonist fadrozole at 5 serial dilutions.

The protein content for each tissue aliquot was measured using a Bradford assay with both the product isolation assay and the water assay. Aromatase is reported as femtomoles of product per minute per milligram of protein. All experimental tissue samples were processed using the water assay. An aliquot of a frozen California mouse brain tissue homogenate pool was included in each assay of experimental tissue. The interassay coefficient of variation for this pool was $7.3 \%$.

\section{Hormone Assays}

Details of hormone assay procedures and assay validation information for the measurement of testosterone [35], DHT [24], and $\mathrm{P}_{4}$ [47] in California mice have been previously described. Briefly, $60-\mu 1$ plasma samples were extracted in ethyl ether and steroid hormones were separated using celite chromatography. Testosterone, DHT, and $\mathrm{P}_{4}$ were measured with enzyme immunoassays. Intra-assay coefficients of variation for testosterone, DHT, and $\mathrm{P}_{4}$ were 4.2, 7.3, and $4.7 \%$. Interassay coefficients of variation were 14.9, 14.9, and $12.8 \%$. 


\section{Data Analysis}

We used Q-Q plots to assess normality and checked cell variances for homogeneity of variance [48]. Based on these analyses we square root-transformed all aromatase activity data and log-transformed all hormonal data. For analyses of aromatase activity data, we used age of subject as a covariate in analyses of covariance and used planned comparisons to compare fathers to inexperienced and mated males. We analyzed hormonal data with one-way ANOVAs and used planned comparisons to compare fathers to inexperienced and mated males. We calculated Pearson correlations between aromatase activity and steroid hormones. Results are reported as mean $\pm \mathrm{SE}$.

\section{Results}

\section{Validation Experiments}

The time course experiments using the product isolation method and water assay produced comparable results, especially considering that different homogenate pools were used for each assay (fig. 1a). Estrogen production increased linearly up to $4 \mathrm{~h}$, and the competitive aromatase antagonist 10-OH-AE effectively inhibited aromatase activity. Fadrozole also inhibited aromatase activity in a dose-dependent manner (fig. 1b). The Ki for fadrozole was $7.3 \mathrm{nmol}$, which is similar to previously published values [49]. In the saturation experiment, the $\mathrm{K}_{\mathrm{m}}$ of the reaction was determined to be $100.9 \mathrm{n} M$, and the $\mathrm{V}_{\max }$ was calculated to be $194.3 \mathrm{fmol} / \mathrm{mg} / \mathrm{min}$. Although our calculated $\mathrm{K}_{\mathrm{m}}$ was higher than most published values for aromatase [e.g. 10], it is close to other published values using similar methodological approaches [50, 51]. Less than $0.5 \%$ of the substrate was converted to product during experimental assays (estimated by measuring radioactivity in the water phase), indicating that the substrate concentration did not limit the rate of the aromatase reaction.

\section{Aromatase Activity and Reproductive Experience}

There were significant differences across experimental groups in aromatase activity in the MPOA (fig. $2 ; \mathrm{F}_{2,36}=$ 4.07; $\mathrm{p}=0.025)$. A planned comparison indicated that fathers had significantly more aromatase activity than mated males $(p<0.01)$ and there was a nonsignificant trend for fathers to have more aromatase activity in the MPOA than inexperienced males $(p=0.06)$. Overall, there was no effect of reproductive experience on aromatase activity within the BNST (fig. $2 ; \mathrm{F}_{2,36}=2.27 ; \mathrm{p}=$ 0.12). However, a planned comparison indicated a nonsignificant trend for fathers to have less aromatase activity than inexperienced males in the BNST $(p=0.05)$. There was no difference in aromatase activity in the

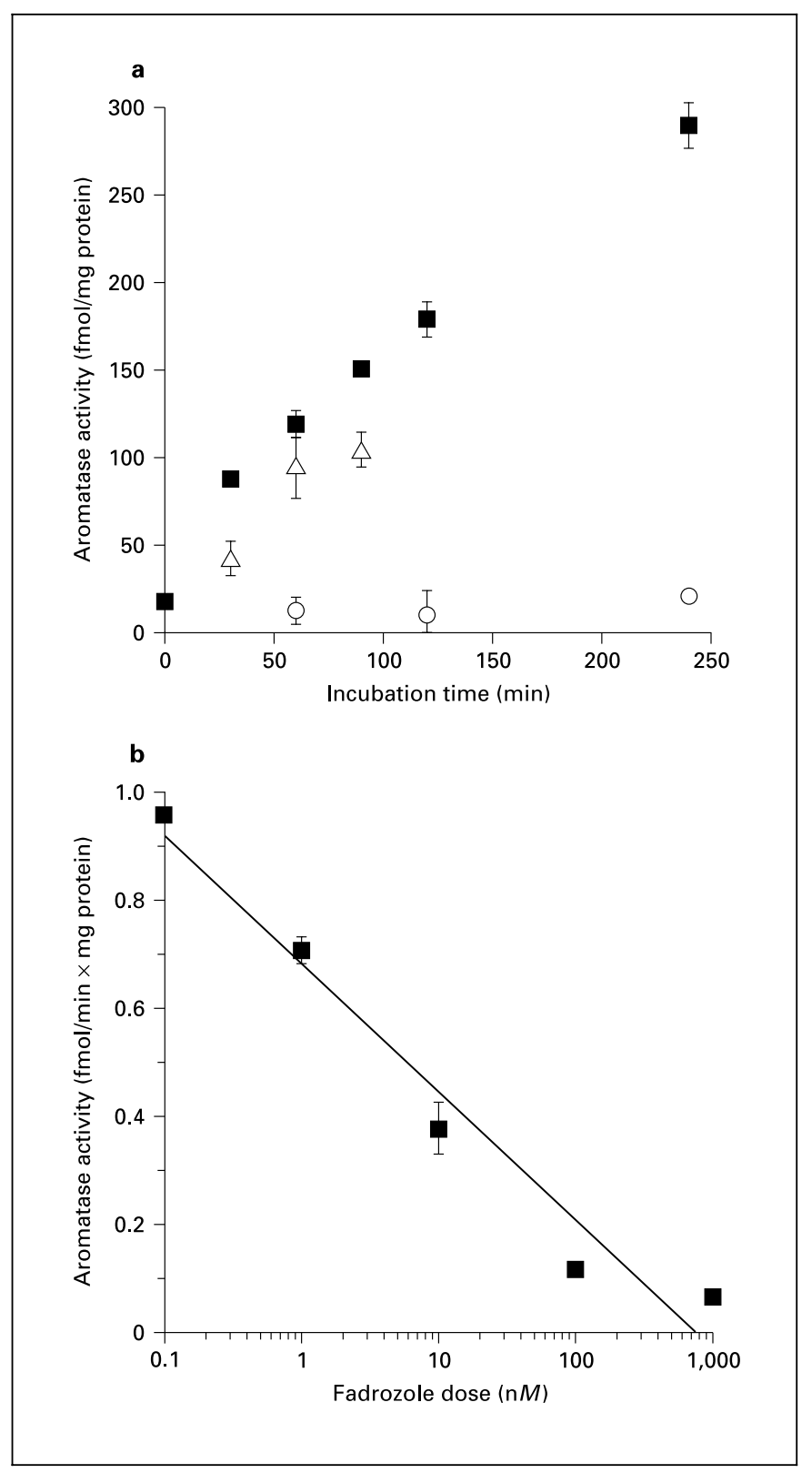

Fig. 1. Validation studies using pools of California mouse brain tissue homogenate. a Time course studies using water assay and product isolation methods. $\Delta=$ Product isolation assay; $\boldsymbol{\square}=$ water assay; $\mathrm{O}=$ water assay $+10 \mu M$ 4-OH-AE. b Water assay, fadrozole doseresponse curve $(\mathrm{Ki}=7.3 \mathrm{n} M)$.

BNST between fathers and mated males. In the VMH, there was no overall effect of reproductive experience on aromatase activity (fig. $2 ; \mathrm{F}_{2,36}=1.46 ; \mathrm{p}=0.25$ ). There were no significant differences in aromatase activity in the MA (fig. 2; $\mathrm{F}_{2,36}=0.60 ; \mathrm{p}=0.55$ ) or HPC (fig. 2; $\left.\mathrm{F}_{2,36}=0.55 ; \mathrm{p}=0.58\right)$. 


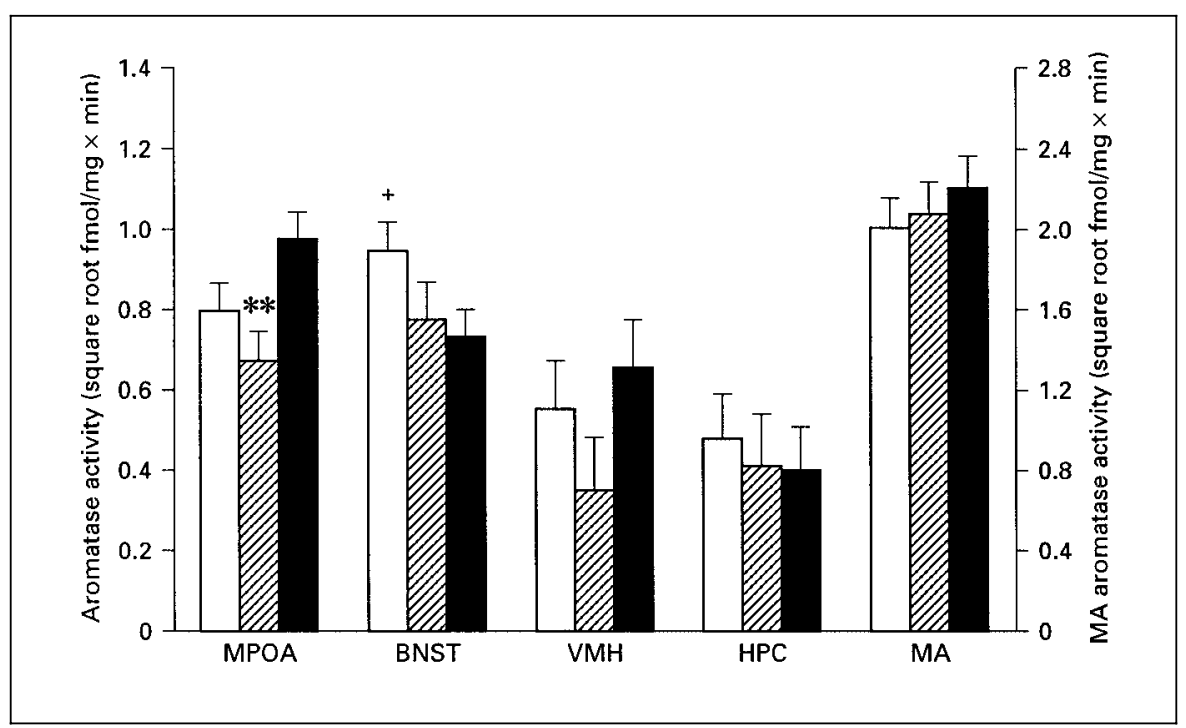

Fig. 2. Aromatase activity in microdissected brain areas in male California mice. Aromatase activity means for the medial preoptic area (MPOA), bed nucleus of the stria terminalis (BNST), ventromedial hypothalamus (VMH), and hippocampus (HPC) correspond to the left axis. Aromatase activity means for the medial amygdala (MA) correspond to the right axis. ${ }^{* *} \mathrm{p}<0.01$ from fathers; ${ }^{+} \mathrm{p}=0.05$ from fathers. $\square=$ Sexually inexperienced males $(\mathrm{n}=14)$; $\square=$ mated males $(\mathrm{n}=11) ; \mathbf{~ = ~ f a t h e r s ~}(\mathrm{n}=15)$. Data are presented as corrected (for age) means \pm standard errors.

Fig. 3. Testosterone (a), dihydrotestosterone (b), and progesterone (c) levels for male California mice. ${ }^{* *} \mathrm{p}=0.001$ from fathers; $* * \mathrm{p}=0.01$ from fathers. $\square=$ Sexually inexperienced males $(\mathrm{n}=13) ; 0=$ mated males $(\mathrm{n}=11) ; \boldsymbol{\nabla}=$ fathers $(\mathrm{n}=15) ;{ }^{*} \mathrm{p}=0.045$ from fathers.
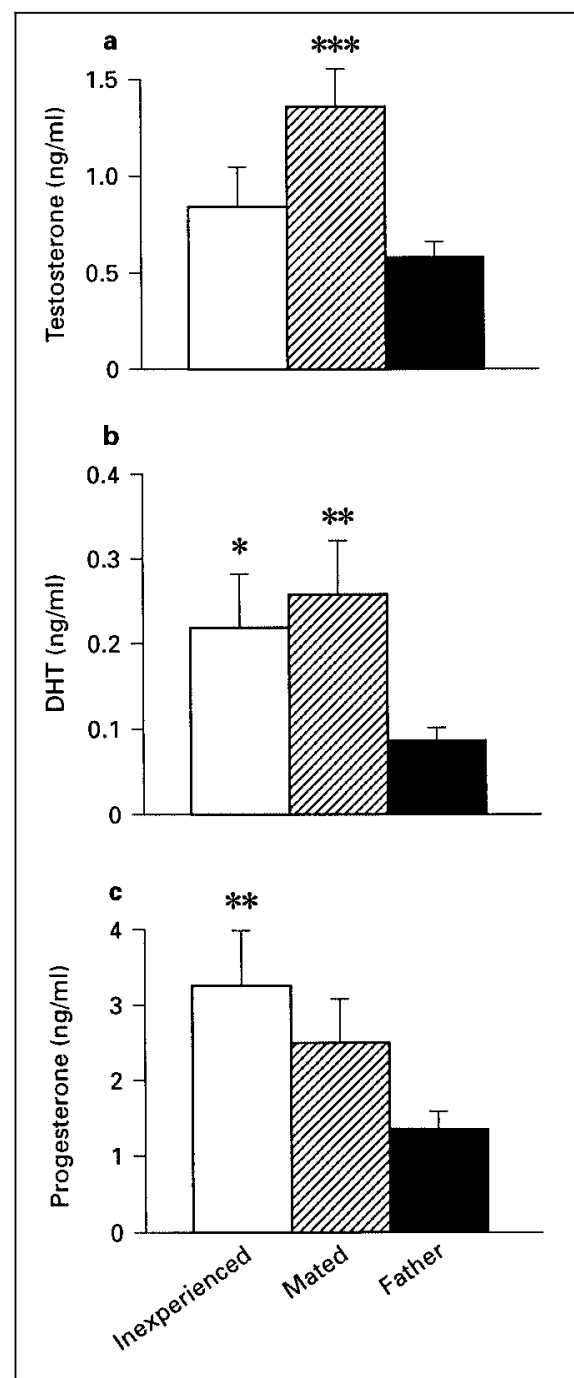

\section{Steroid Hormones and Reproductive Experience}

We found that testosterone levels differed in males with different reproductive experience (fig. $3 \mathrm{a} ; \mathrm{F}_{2,36}=$ $6.38, \mathrm{p}=0.004)$. Fathers had significantly lower testosterone levels than mated males $(p=0.001)$ but did not differ from inexperienced males $(p=0.32)$. DHT levels also differed among groups (fig. $3 b ; F_{2,36}=4.0, p=0.027$ ). Fathers had significantly lower DHT levels than mated males $(p=0.01)$ and inexperienced males $(p=0.045)$. Neither testosterone nor DHT levels were correlated with aromatase activity in any brain area (fig. 4; all $\mathrm{p}>0.08$ ).

We found that $\mathrm{P}_{4}$ levels differed in males with different reproductive experience (fig. $3 c ; F_{2,36}=3.97 p=0.028$ ). Fathers had significantly lower $\mathrm{P}_{4}$ levels compared to inexperienced males $(p=0.01)$ and there was a nonsignifi- cant trend for fathers to have lower $\mathrm{P}_{4}$ levels than mated males $(p=0.078)$. Across all 3 groups, $P_{4}$ was negatively correlated with aromatase activity in the MPOA (fig. 5; $r=-0.33, n=39, p=0.045)$. This correlation was not solely driven by between-group changes in $\mathrm{P}_{4}$ and aromatase, as this negative correlation was significant when fathers were considered alone (fig. $5 ; \mathrm{r}=-0.53, \mathrm{n}=15, \mathrm{p}=$ $0.04)$. Although there was weak evidence that this relationship may persist in mated males (fig. $5 ; \mathrm{r}=-0.49, \mathrm{n}=$ $11, \mathrm{p}=0.13$ ), there was no evidence that $\mathrm{P}_{4}$ levels are associated with aromatase activity in sexually inexperienced males (fig. 5; $\mathrm{r}=0.29, \mathrm{n}=12, \mathrm{p}=0.35$ ).

Finally, $\mathrm{P}_{4}$ levels in singly housed males $(\mathrm{n}=18,1.88$ $\pm 0.28 \mathrm{ng} / \mathrm{ml})$ and group housed males $(\mathrm{n}=12,1.93 \pm$ $0.35 \mathrm{ng} / \mathrm{ml})$ were not significantly different $\left(\mathrm{t}_{28}=0.31, \mathrm{p}=\right.$ 


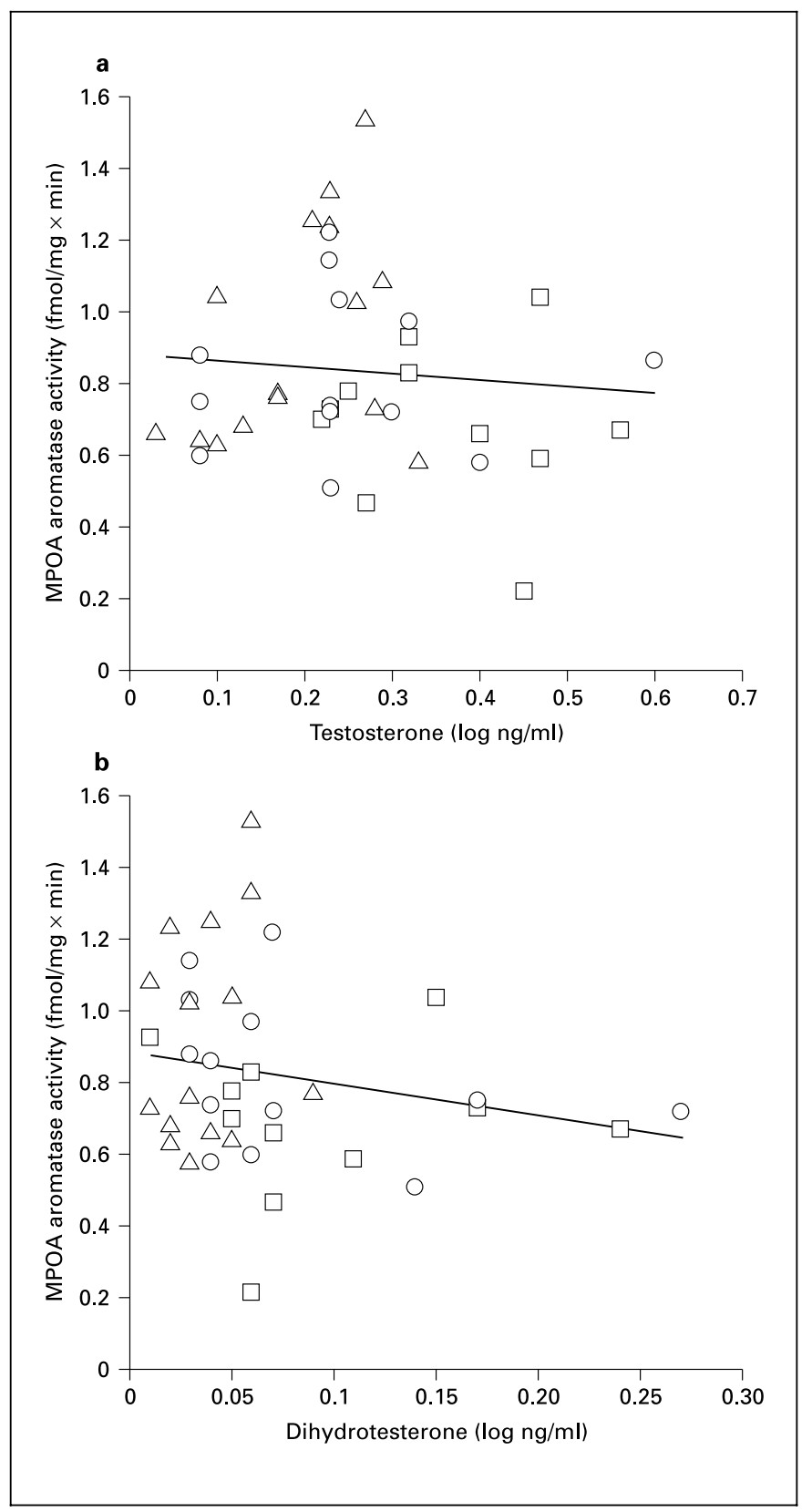

Fig. 4. Aromatase activity in the medial preoptic area (MPOA) plotted against testosterone (a), and dihydrotestosterone (b). $\square=$ Sexually inexperienced males $(\mathrm{n}=13) ; \mathrm{O}=$ mated males $(\mathrm{n}=11) ; \Delta=$ fathers $(n=15)$.

0.75). We also found that castrated males had measurable amounts circulating $\mathrm{P}_{4}(\mathrm{n}=22,2.78 \pm 0.57 \mathrm{ng} / \mathrm{ml})$, and were not significantly different from singly housed males $\left(\mathrm{t}_{38}=1.38, \mathrm{p}=0.17\right)$ or group housed males $\left(\mathrm{t}_{32}=0.94, \mathrm{p}=\right.$ $0.35)$.

Preoptic Aromatase and Paternal Behavior

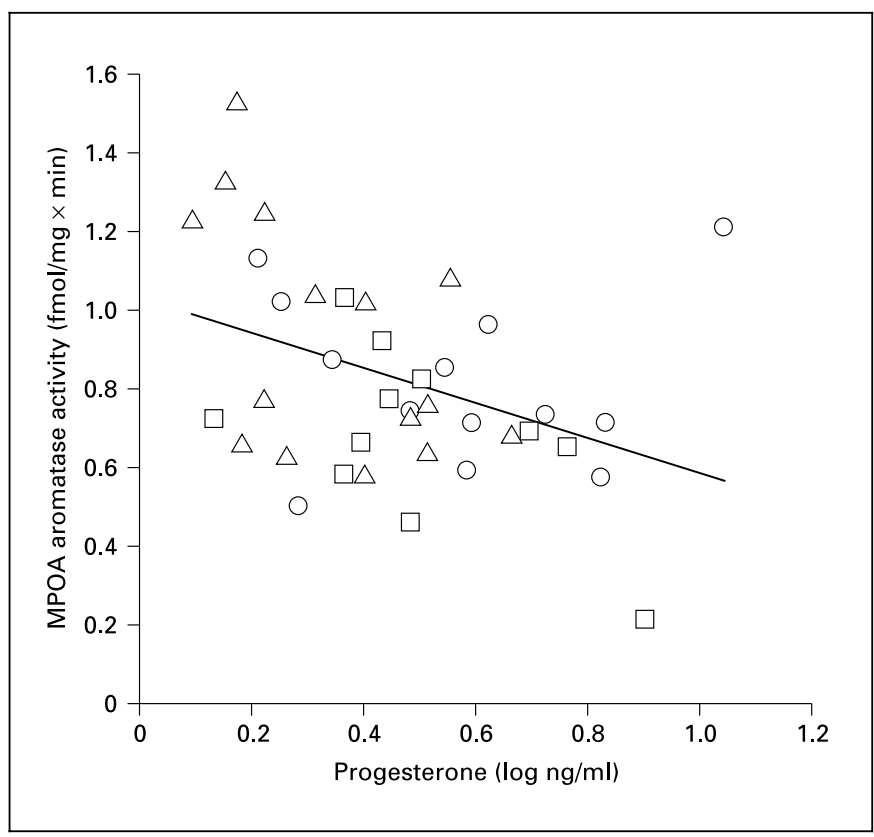

Fig. 5. Aromatase activity in the medial preoptic area (MPOA) plotted against progesterone. $\square=$ Sexually inexperienced males $(\mathrm{n}=13)$; $O=$ mated males $(n=11) ; \Delta=$ fathers $(n=15)$.

\section{Discussion}

While many studies have observed that peripheral hormone levels change when males become fathers, less is known about any accompanying neuroendocrine changes in the brain. We found that fathers have significantly more aromatase activity in the MPOA than mated males, and tend to have more enzyme activity than sexually inexperienced males. This finding agrees with previous studies that found that $\mathrm{E}_{2}$ promotes paternal behavior in male California mice [24] and that the MPOA is an important brain area for the expression of parental behaviors [37]. This increase in aromatase activity coincides with the onset of paternal behavior $[25,26]$, suggesting that increased aromatase activity in the MPOA may contribute to the onset of paternal behavior. We also found that $\mathrm{P}_{4}$ levels were reduced in fathers, which to our knowledge, has not been previously reported in a biparental mammal.

The amount of available $\mathrm{E}_{2}$ in the MPOA can be altered in several ways including changing substrate concentration, cofactors and accessory proteins, nitric oxide concentrations, and aromatase enzyme concentration [52]. Consistent with previous reports in paternal rodents $[25,27,28]$, we found no difference in testosterone

Neuroendocrinology 2003;78:36-44 
between sexually inexperienced males and fathers. Therefore, it is unlikely that fathers could increase $E_{2}$ in the MPOA via an increase in substrate concentration. In contrast, we found that increased aromatase activity in the MPOA was associated with the onset of paternal behavior. Our previous work showed that $\mathrm{E}_{2}$ promotes paternal behavior in fathers, but is undetectable in intact male plasma [24], suggesting that aromatization occurs within the brain. In gonadectomized male rats treated with $E_{2}$ and $\mathrm{P}_{4}$ implants, $\mathrm{E}_{2}$ implants in the MPOA increased parental behavior, even though male rats normally do not act parentally towards pups [38]. While intriguing, the rats in that study did not have the hormonal milieu typically found in intact paternal mammals. However, studies in paternal rodents confirm that the MPOA regulates paternal behavior. Biparental male prairie voles show increased neuronal activity in the MPOA as measured by c-Fos expression after exposure to pups [53], and electrolytic lesions of the MPOA reduce paternal behaviors in male California mice [39]. The MPOA could also become more sensitive to $\mathrm{E}_{2}$ via a change in receptor number, as a study on a paternal strain of domestic mice found more cells containing estrogen receptors in the MPOA of reproductively experienced males than virgin males [54]. There is evidence that the $\alpha$-estrogen receptor in particular may be important for parental behavior. Selective deletion of the $\alpha$-estrogen receptor gene in mice resulted in severe deficits in maternal behavior [55], whereas no deficits in maternal behavior were reported in mice lacking the $\beta$ estrogen receptor gene [56].

There was little evidence that changes in aromatase activity were associated with the previously described inhibitory circuit of parental behavior $[40,41]$. We saw no differences in aromatase activity within the MA or VMH. The apparent change in aromatase activity in the BNST could be associated with changes in aggression. Male prairie voles became more aggressive after pair bonding [57] and male hamsters showed increased immediate early gene expression in the BNST after aggressive interactions $[58,59]$. In the California mouse, aromatase activity in the BNST is positively correlated with latency to attack an intruder in a resident-intruder aggression test, and fadrozole decreases attack latency [Trainor et al., in preparation]. Overall, changes in aromatase activity in male California mice appear to be more closely associated with the activation of neural mechanisms that promote paternal behavior, rather than inactivation of inhibitory mechanisms.

Previous studies observing hormonal changes associated with the onset of paternal behavior have focused main- ly on androgens and prolactin [27-30]. We found that fathers had lower $\mathrm{P}_{4}$ levels than sexually inexperienced males. The higher $\mathrm{P}_{4}$ levels of sexually inexperienced males cannot be attributed to the standard laboratory practice of housing multiple males together, since $\mathrm{P}_{4}$ levels of group housed males did not differ from singly housed males. The primary source of $\mathrm{P}_{4}$ in the California mouse is most likely the adrenal, as $\mathrm{P}_{4}$ levels of castrated males were not different from intact males, and previous studies in mammals have found that the adrenal secretes $\mathrm{P}_{4}[60,61]$. However, we cannot exclude the possibility that the brain contributes to some of the $\mathrm{P}_{4}$ detected in blood [62]. $\mathrm{P}_{4}$ receptor knock-out mice exhibit reduced infanticide and increased levels of paternal behavior, while the $\mathrm{P}_{4}$ antagonist RU486 increased paternal behavior in wild-type C57BL mice [63]. These findings suggest that decreased $\mathrm{P}_{4}$ may contribute to the onset of paternal behavior in California mouse fathers. High doses of exogenous $\mathrm{P}_{4}$ have been shown to inhibit testosterone-dependent sexual behaviors in male mice [64] and rhesus monkeys [65], suggesting that $\mathrm{P}_{4}$ could have a similar inhibitory effect on testosterone-dependent paternal behavior in California mice. However, treatments using physiological doses have found that $\mathrm{P}_{4}$ can enhance sexual behaviors in male rats [66]. Thus, experimental manipulations of $\mathrm{P}_{4}$ will be required to determine the effect of $\mathrm{P}_{4}$ on paternal behavior in California mice.

We found that $\mathrm{P}_{4}$ was negatively correlated with aromatase activity within the MPOA both across groups and within fathers. Most previous studies have found that hypothalamic aromatase activity is androgen-dependent in Sprague-Dawley rats [10], rhesus monkeys [8], and sheep [7]. However, neither testosterone nor DHT was correlated with aromatase activity in any of the brain areas we examined. It is possible that androgen measurements taken at a different time of day would correlate more closely with aromatase activity, or that the increase in testosterone observed in mated males increased aromatase via a delayed response. However, there is evidence for variation in the control of aromatase activity. Castration did not reduce aromatase activity in the MPOA of Long-Evans rats [67] or in the BNST of rhesus monkeys [8], and most studies have found that aromatase activity in the cortical amygdala is largely androgen-independent $[8,10]$. Further research is needed to determine whether physiological levels of $\mathrm{P}_{4}$ and testosterone regulate aromatase in male California mice.

Our results show that the onset of paternal behavior is associated with an increase in MPOA aromatase activity and a decrease in $\mathrm{P}_{4}$. This increase in aromatase activity 
cannot be explained by an increase in testosterone levels, and could reflect variation in the steroidal regulation of aromatase in the brain. $\mathrm{P}_{4}$ inhibits paternal behavior in domestic mice, and the selective deletion of the $\mathrm{P}_{4}$ receptor leads to an increase in paternal behavior [63]. One question that is still unknown is whether $\mathrm{P}_{4}$ is involved in the onset of paternal behavior, maintenance of paternal behavior, or both. Decreased $\mathrm{P}_{4}$ could trigger the onset of parental behavior by allowing the initial activation of estrogen-based mechanisms of paternal behavior, similar to how estrogen promotes the onset of maternal behavior [37]. In contrast, decreased $\mathrm{P}_{4}$ could be necessary for the continued expression of paternal behavior. Further experimentation will be needed to elucidate the role of $\mathrm{P}_{4}$ in mediating paternal behavior in biparental mammals. In general, our results indicate that aromatase activity and steroid hormone levels change in association with an important life history transition in a biparental mammal.

\section{Acknowledgments}

We thank C.W. Berridge, P. Martin and M. Swaab for technical assistance; P. Cofta for animal husbandry; D.H. Abbot, C.T. Snowdon, and 2 anonymous reviewers for comments on the manuscript. Hormone assays were conducted at the Wisconsin Primate Research Center Assay Laboratory. The research presented here was described in Animal Research Protocol A-48-7400-L00221-3-01-00 approved on May 31, 2000 by the UW Research Animal Resource Committee. This research was supported by NIH National Research Service Award F31 MH64328-01 from the NIMH to B.C.T., MH61994 to B.A.S., and NSF Grant IBN - 9703309 to C.A.M.

\section{References}

1 Adkins-Regan E: Hormonal mechanisms of mate choice. Am Zool 1998;38:166-178.

2 Schlinger BA, Callard GV: Aromatization mediates aggressive behavior in quail. Gen Comp Endocrinol 1990;79:39-53.

3 Simon NG, Lu SF, McKenna SE, Chen X, Clifford AC: Sexual dimorphisms in regulatory systems for aggression; in Haug M, Whalen RE, Aron C, Olsen KL (eds): The Development of Sex Differences and Similarities in Behavior. Boston, Kluwer Academic Press, 1993, pp 389-408.

4 Balthazart J, Surlemont C: Androgen and estrogen action in the preoptic area and activation of copulatory behavior in quail. Physiol Behav 1990;48:599-609.

5 Baum MJ: Neuroendocrinology of sexual behavior in the male; in Becker JB, Breedlove SM, Crews D, McCarthy M (eds): Behavioral Endocrinology, ed 2. Cambridge, MIT Press, 2002, pp 153-204.

6 Fadem BH, Walters MJ, MacLusky N: Neural aromatase activity in a marsupial, the gray short tailed opossum (Monodelphis domestica). Ontogeny during postnatal development and androgen regulation in adulthood. Dev Brain Res 1993;74:199-205.

7 Roselli CE, Stormshak F, Resko JA: Distribution and regulation of aromatase activity in the ram hypothalamus and amygdala. Brain Res 1998;811:105-110.

8 Roselli CE, Resko JA: Testosterone regulates aromatase activity in discrete brain areas of male rhesus macaques. Biol Reprod 1989;40: 929-934.

9 Hutchison RE, Hutchison JB, Steimer T, Steel E, Powers JB, Walker AP, Herbert J, Hastings $\mathrm{MH}$ : Brain aromatization of testosterone in the male Syrian hamster - Effects of androgen and photoperiod. Neuroendocrinology 1991;53: 194-203.
10 Roselli CE, Klosterman SA, Fasasi TA: Sex differences in androgen responsiveness in the rat brain: Regional differences in the induction of aromatase activity. Neuroendocrinology 1996; 64:139-145.

11 Balthazart J, Foidart A: Brain aromatase and the control of male sexual behavior. J Steroid Biochem Mol Biol 1993;44:521-540.

12 Baum MJ, Vreeburg JTM: Copulation in castrated male rats following combined treatment with estradiol and dihydrotestosterone. Science 1973; 182:283-284.

13 Roselli CE, Horton LE, Resko JA: Distribution and regulation of aromatase activity in the rat hypothalamus and limbic system. Endocrinology $1985 ; 117: 2471-2477$.

14 Clancy AN, Zumpe D, Michael RP: Intracerebral infusion of an aromatase inhibitor, sexual behavior and brain estrogen receptor-like immunoreactivity in intact male rats. Neuroendocrinology 1995;61:98-111.

15 Newman SW: The medial extended amygdala in male reproductive behavior. Ann NY Acad Sci 1999;877:242-257.

16 Sachs BD, Meisel RL: The physiology of male sexual behavior; in Knobil E, Neil J (eds): The Physiology of Reproduction. New York, Raven Press, 1994, pp 3-105.

17 Compaan JC, Hutchinson JB, Wozniak A, Ruiter AJH, Koolhaas JM: Brain aromatase activity and plasma testosterone levels are elevated in aggressive male mice during early ontogeny. Dev Brain Res 1994;82:185-192.

18 Resko JA, Perkins A, Roselli CE, Fitzgerald JA, Choate JVA, Stormshak F: Endocrine correlates of partner preference behavior in rams. Biol Reprod 1996;55:120-126.

19 Breedlove SM: Sex on the brain. Nature 1998; 389:801.
20 Francis RC, Soma K, Fernald RD: Social regulation of the brain-pituitary-gonadal axis. Proc Natl Acad Sci USA 1993;90:7794-7798.

21 Erksine MS, Tobet SA, Baum MJ: Effects of birth on plasma testosterone, brain aromatase activity, and hypothalamic estradiol in male and female ferrets. Endocrinology 1998;122: 524-530.

22 Riters LV, Baillien M, Eens M, Pinxten R, Foidart A, Ball GF, Balthazart J: Seasonal variation in androgen-metabolizing enzymes in the diencephalon and telencephalon of the male European starling (Sturnus vulgaris). J Neuroendocrinol 2001;13:985-997.

23 Soma KK, Bindra RK, Gee J, Wingfield JC, Schlinger BA: Androgen-metabolizing enzymes show region-specific changes across the breeding season in the brain of a wild songbird. $\mathrm{J}$ Neurobiol 1999;41:176-188.

24 Trainor BC, Marler CA: Testosterone promotes paternal behaviour via conversion to oestrogen in a monogamous mammal. Proc R Soc Lond B 2002;269:823-829.

25 Gubernick DJ, Nelson RJ: Prolactin and paternal behavior in the biparental California mouse, Peromyscus californicus. Horm Behav 1989;23:203-210.

26 Gubernick DJ, Schneider KA, Jeannotte LA: Individual differences in the mechanisms underlying the onset and maintenance of paternal behavior and the inhibition of infanticide in the monogamous biparental California mouse, Peromyscus californicus. Behav Ecol Sociobiol 1994;34:225-231.

27 Brown RE, Murdoch T, Murphy PR, Moger WH: Hormonal responses of male gerbils to stimuli from their mate and pups. Horm Behav 1995;29:474-491.

28 Reburn CJ, Wynne-Edwards KE: Hormonal changes in males of a naturally biparental and a uniparental mammal. Horm Behav 1999;35: 163-176. 
29 Ziegler TE, Snowdon CT: Preparental hormone levels and parenting experience in male cotton-top tamarins, Saguinus oedipus. Horm Behav 2001;38:59-167.

30 Nunes S, Fite JE, Patera KJ, French JA: Interactions among paternal behavior, steroid hormones, and parental experience in male marmosets (Callithrix kuhlii). Horm Behav 2001; 39:70-82.

31 Clark MM, Galef BG Jr: A testosterone-mediated trade-off between parental and sexual effort in male Mongolian gerbils (Meriones unguiculatus). J Comp Psychol 1999;113:388395.

32 Lonstein JS, De Vries GJ: Sex differences in the parental behaviour of adult virgin prairie voles: Independence from gonadal hormones and vasopressin. J Neuroendocrinol 1999;11: 441-449.

33 Wang Z, De Vries GJ: Testosterone effects on paternal behavior and vasopressin immunoreactive projections in prairie voles (Microtus ochrogaster). Brain Res 1993;631:156-160.

34 Lonstein JS, Rood BD, De Vries GJ: Parental responsiveness is feminized after neonatal castration in virgin male prairie voles but is not masculinized by perinatal testosterone in virgin females. Horm Behav 2002;41:80-87.

35 Trainor BC, Marler CA: Paternal behavior, aggression, and testosterone in the California mouse, Peromyscus californicus. Horm Behav 2001;40:32-42.

36 Marler CA, Bester-Meredith JK, Trainor BC: Paternal behavior and aggression: Endocrine mechanisms and nongenomic transmission of behavior. Adv Study Behav 2003;32:263-323.

37 Bridges RS: Biochemical basis of parental behavior in the rat. Adv Stud Behav 1996;25: 215-242.

38 Rosenblatt JS, Ceus K: Estrogen implants in the medial preoptic area stimulate maternal behavior in male rats. Horm Behav 1998;33: 23-30.

39 Lee AW, Brown RE: Medial preoptic lesions disrupt parental behavior in both male and female California mice. Behav Neurosci 2002; 116:968-975.

40 Fleming AS, Vaccarino F, Luebke C: Amygdaloid inhibition of maternal behavior in the nulliparous female rat. Physiol Behav 1980;25: 731-743.

41 Sheehan T, Paul M, Amaral E, Numan MJ, Numan M: Evidence that the medial amygdala projects to the anterior/ventromedial hypothalamic nuclei to inhibit maternal behavior in rats. Neuroscience 2001;106:341-356.
42 Berridge CW, Mitton E, Clark W, Roth RH: Engagement in a non-escape (displacement) behavior elicits a selective and lateralized suppression of frontal cortical dopaminergic utilization in stress. Synapse 1999;32:187-197.

43 Lephart ED, Simpson ER: Assay of aromatase activity. Methods Enzymol 1991;206:44134420.

44 Schlinger BA, Callard GV: A comparison of aromatase, $5 \alpha$ - and $5 \beta$-reductase in brain and pituitary of male and female Japanese quail (Coturnix coturnix japonica). J Exp Zool 1987; 242:171-180.

45 Bird IM, Pasquarette MM, Rainey WE, Mason JI: Hydroxysteroid dehydrogenase expression in human adrenocortical H295R cells. J Clin Endocrinol Metab1996;81:2171-2178.

46 Marsh DA, Brodie HJ, Garrett WM, Tsai-Morris $\mathrm{CH}$, Brodie $\mathrm{AMH}$ : Aromatase inhibitors Synthesis and biological activity of androstenedione derivatives. J Med Chem 1985;28:788795.

47 Davis ES, Marler CA: The progesterone challenge: steroid changes following an aggressive encounter in female Peromyscus californicus. Horm Behav, in press.

48 Zar JH: Biostatistical Analysis. Prentice-Hall, Englewood Cliffs, 1996.

49 Odum J, Ashby J: Detection of aromatase inhibitors in vitro using rat ovary microsomes. Toxicol Lett 2002;129:119-122.

50 Chabab A, Nicolas JC, Sultan C: Aromatase activity in human skin fibroblasts: Characterization by an enzymatic method. J Steroid Biochem 1986;25:157-163.

51 Dao TL: Estrogen synthesis in human breast tumor and its inhibition by testololactone and bromoandrostenedione. Cancer Res 1982;42 (8 suppl):3338S-3341S.

52 Bird IM, Conley AJ: Steroid biosynthesis: Enzymology, integration and control; in Mason JI (ed): Genetics of Steroid Biosynthesis and Function. New York, Routledge, 2002, pp 135 .

53 Kirkpatrick B, Kim JW, Insel TR: Limbic system fos expression associated with paternal behavior. Brain Res 1994;658:112-118.

54 Ehret G, Jürgens A, Koch M: Oestrogen receptor occurrence in the male mouse brain: modulation by paternal experience. Neuroreport 1993;4:1247-1250.

55 Ogawa S, Eng V, Taylor J, Lubahin DB, Korach KS, Pfaff DW: Roles of estrogen receptor$\alpha$ gene expression in reproduction-related behaviors in female mice. Endocrinology 1998; 139:5070-5081.
56 Krege JH, Hodgin JB, Couse JF, Enmark E, Warner W, Mahler JF, Sar M, Korach KS, Gustafsson J, Smithies O: Generation and reproductive phenotypes of mice lacking estrogen receptor $\beta$. Proc Natl Acad Sci USA 1998;95: 15677-15682.

57 Winslow JT, Hastings N, Carter CS, Harbaugh CR, Insel TR: A role for central vasopressin in pair bonding in monogamous prairie voles. $\mathrm{Na}$ ture 1993;365:545-548.

58 Delville Y, De Vries GJ, Ferris CF: Neural connections of the anterior hypothalamus and agonistic behavior in golden hamsters. Brain Behav Evol 2000;55:53-76.

59 Kollack-Walker S, Newman SW: Mating and agonistic behavior produce different patterns of fos immunolabeling in the male Syrian hamster brain. Neuroscience 1995;66:721-736.

60 Piva F, Gagliano P, Motta M, Martini L: Adrenal progesterone: Factors controlling its secretion. Endocrinology 1973;93:1178-1184.

61 Van Lier E, Regueiro M, Pérez-Clariget R, Andersson H, Kindahl H, Forsberg M: Effects of adrenocorticotrophin (ACTH) and progesterone on luteinising hormone (LH) secretion in recently castrated rams. Anim Reprod Sci 1999;55:115-126.

62 Baulieu EE, Robel P, Schumacher M: Neurosteroids: A New Regulatory Function in the Nervous System. Totowa, Humana Press, 1999.

63 Schneider JS, Stone MK, Wynne-Edwards KE, Horton TH, Lydon J O'Malley B, Levine JE: Progesterone receptors mediate male aggression toward infants. Proc Natl Acad Sci USA 2003; 100:2951-2956.

64 Erpino MJ: Temporary inhibition by progesterone of sexual behavior in intact male mice. Horm Behav 1973;4:335-339.

65 Zumpe D, Bonsall RW, Michael RP: Effects of the nonsteroidal aromatase inhibitor, fadrozole, on the sexual behaviour of male cynomolgus monkeys (Macaca fascicularis). Horm Behav 1993;27:200-215.

66 Witt DM, Young LJ, Crews D: Progesterone modulation of androgen-dependent sexual behavior in male rats. Physiol Behav 1995;57: 307-313.

67 Lephart ED, Butler PC, Mills RH, Jacobson NA, Ladle DR, Bloch GJ: Effects of testosterone and progesterone on brain $5 \alpha$-reductase and aromatase in Long-Evans males and comparison of aromatase in Long-Evans vs. Sprague-Dawley rats. Brain Res 1998;789: 327-330. 